\title{
Restoration of Rangelands Invaded by Amelichloa clandestina (Hack.) Arriaga \& Barkworth after 12 Years of Agriculture Abandonment (Coahuila, Mexico)
}

\author{
José R. Arévalo ${ }^{1}$, Juan A. Encina-Domínguez ${ }^{2, *}$, Sait Juanes-Márquez ${ }^{2}$, Perpetuo Álvarez-Vázquez ${ }^{2}$, \\ Juan A. Nuñez-Colima ${ }^{2}$ and Miguel Mellado ${ }^{3}$
}

Citation: Arévalo, J.R.; EncinaDomínguez, J.A.; Juanes-Márquez, S.; Álvarez-Vázquez, P.; Nuñez-Colima,

J.A.; Mellado, M. Restoration of

Rangelands Invaded by Amelichloa

clandestina (Hack.) Arriaga \&

Barkworth after 12 Years of

Agriculture Abandonment (Coahuila,

Mexico). Agriculture 2021, 11, 886.

https://doi.org/10.3390/

agriculture11090886

Academic Editor: Michele Scotton

Received: 28 July 2021

Accepted: 8 September 2021

Published: 15 September 2021

Publisher's Note: MDPI stays neutral with regard to jurisdictional claims in published maps and institutional affiliations.

Copyright: (c) 2021 by the authors. Licensee MDPI, Basel, Switzerland. This article is an open access article distributed under the terms and conditions of the Creative Commons Attribution (CC BY) license (https:// creativecommons.org/licenses/by/ $4.0 /)$.
1 Department of Botany, Ecology and Plant Physiology, University of La Laguna, 38206 La Laguna, Spain; jarevalo@ull.edu.es

2 Departament of Natural Resources, Autonomous Agrarian University Antonio Narro, Saltillo 25315, Mexico; p_sait.juanesm@uaaan.edu.mx (S.J.-M.); perpetuo.alvarezv@uaaan.edu.mx (P.Á.-V.); juan.anunezc@uaaan.edu.mx (J.A.N.-C.)

3 Department of Animal Nutrition, Autonomous Agrarian University Antonio Narro, Saltillo 25315, Mexico; miguel.mellado@uaaan.edu.mx

* Correspondence: juan.encinad@uaaan.edu.mx

\begin{abstract}
Abandonment of agricultural land is currently one of the main land use changes in developed countries. This change has an impact at the economic level and from the point of view of conservation. Therefore, recovering these areas after abandonment is, in many cases, necessary for ecological restoration, especially as they can be invaded by exotic or dominant species, preventing recovery of the original plant species community. The objective of this study is to examine changes in plant species richness and composition after the application of different treatments to eliminate Amelichloa clandestina, a species that dominates pastures abandoned 12 years ago in an area located in northern Mexico. The area is a semi-desert grassland dominated by buffalo grass Bouteloua dactyloides. We used different eradication techniques such as burning, herbicides, and clipping. Although the treatments had significant effects on species richness and composition and resulted in a relative reduction of the target species, the abundance of Amelichloa clandestina was still substantial. Burning is effective, favoring the increase of species richness and provoking a lower presence of $A$. clandestine but with a dominance of annuals. The most important impact on the total cover of $A$. clandestina is shown by the herbicide treatment. However, monitoring of these areas will still be required to consider the long-term impact and success of treatments.
\end{abstract}

Keywords: biodiversity; DCA; species richness; restoration

\section{Introduction}

Urbanization and the abandonment of agricultural land are currently among the main changes in land use in developed countries [1] and can lead to loss of diversity and cultural values [2,3]. Moreover, a further increase in land abandonment is anticipated in the near future [4].

In general, the cessation of extensive farming in the developing world has led to a substantial increase in dry grasslands and dwarf shrublands in marginal lands [5]. Such changes in vegetation patterns may be an indication of the onset of desertification in arid areas. However, in some cases, positive aspects can arise from land abandonment such as changes in vegetation cover, affecting water availability and soil properties [6,7]. The abandonment of traditional agricultural lands in some areas often leads to fields that require restoration. Indeed, intensive agriculture in the past and rapid environmental change are hindering original plant community recovery. Thus, the restoration of these abandoned fields should be considered a requirement $[8,9]$. 
After abandonment, the dominance of some species (including exotic species) may alter patterns of vegetation recovery in disturbed sites [9], even where native species have enough propagules to recolonize through natural dispersal [10-12]. Thus, management through different tools is required to restore, to some degree, the ecological processes of the plant community (native species, regeneration, species richness, etc.) [13,14].

In this study, we evaluated an area that after 12 years of agriculture abandonment has been completely dominated by Mexican needlegrass (Amelichloa clandestina), unpalatable for vertebrate grazers and native to northern Mexico. This species has been expanding across abandoned fields in northern Mexico and Texas [15]. Changes after agriculture abandonment are evident in many aspects, and the most relevant are related to erosion, changes in nutrients, and alteration of ecological processes such as species richness and maintenance $[16,17]$. Therefore, the objective of this study is to examine changes in plant species richness and composition after the application of different treatments to eliminate a species that dominates pastures due to agriculture abandonment. Elimination was conducted through chemical methods, clipping, and burning to evaluate the restoration possibilities of these management tools. We hypothesized that burning would increase species richness due to the clearing of the biomass and nutrient incorporation through mineralization, while herbicide and clipping would have a more significant effect on the $A$. clandestina cover due to elimination after six months of treatment application.

The study of agriculture abandonment has potential management and environmental implications (species conservation, control of invasive species, etc.) that can be considered relevant to avoid land degradation.

\section{Materials and Methods}

\subsection{Study Site}

The study was carried out at the Los Angeles ranch, located $34 \mathrm{~km}$ south of Saltillo, Coahuila, Mexico, between $25^{\circ} 04^{\prime} 12^{\prime \prime}-25^{\circ} 08^{\prime} 51^{\prime \prime}$ north latitude and $100^{\circ} 58^{\prime} 07^{\prime \prime}-101^{\circ} 03^{\prime} 12^{\prime \prime}$ west longitude; the mean altitude is $2150 \mathrm{~m}$ (Figure 1). The climate according to García [18], using the climate formula (BWhw $\left(\mathrm{x}^{\prime}\right)(\mathrm{e})$ ), is semi-arid, with cool winters, average annual temperature between 18 and $22{ }^{\circ} \mathrm{C}$, and average annual rainfall of 450 to $550 \mathrm{~mm}$, distributed mainly in the summer. The soils are of alluvial origin, deep with well-defined profiles and horizons; they are brown and light reddish-brown in color. The soil type is Calcaric Feozem [19]. The study area is surrounded by a native semi-desert grassland dominated by buffalo grass Bouteloua dactyloides (Nutt.) Columbus, with other dominant grasses as Muhlenbergia phleoides (Kunth) Columbus, M. arenicola Buckley, and the forb Dyschoriste linearis (Torr. \& A. Gray) Kuntze. With an isolated distribution, we can find shrubs of the species Opuntia engelmanii, Salm-Dyck, Cylindropuntia imbricata (Haw.) F.M. Knuth, and Buddleja scordioides Kunth. 


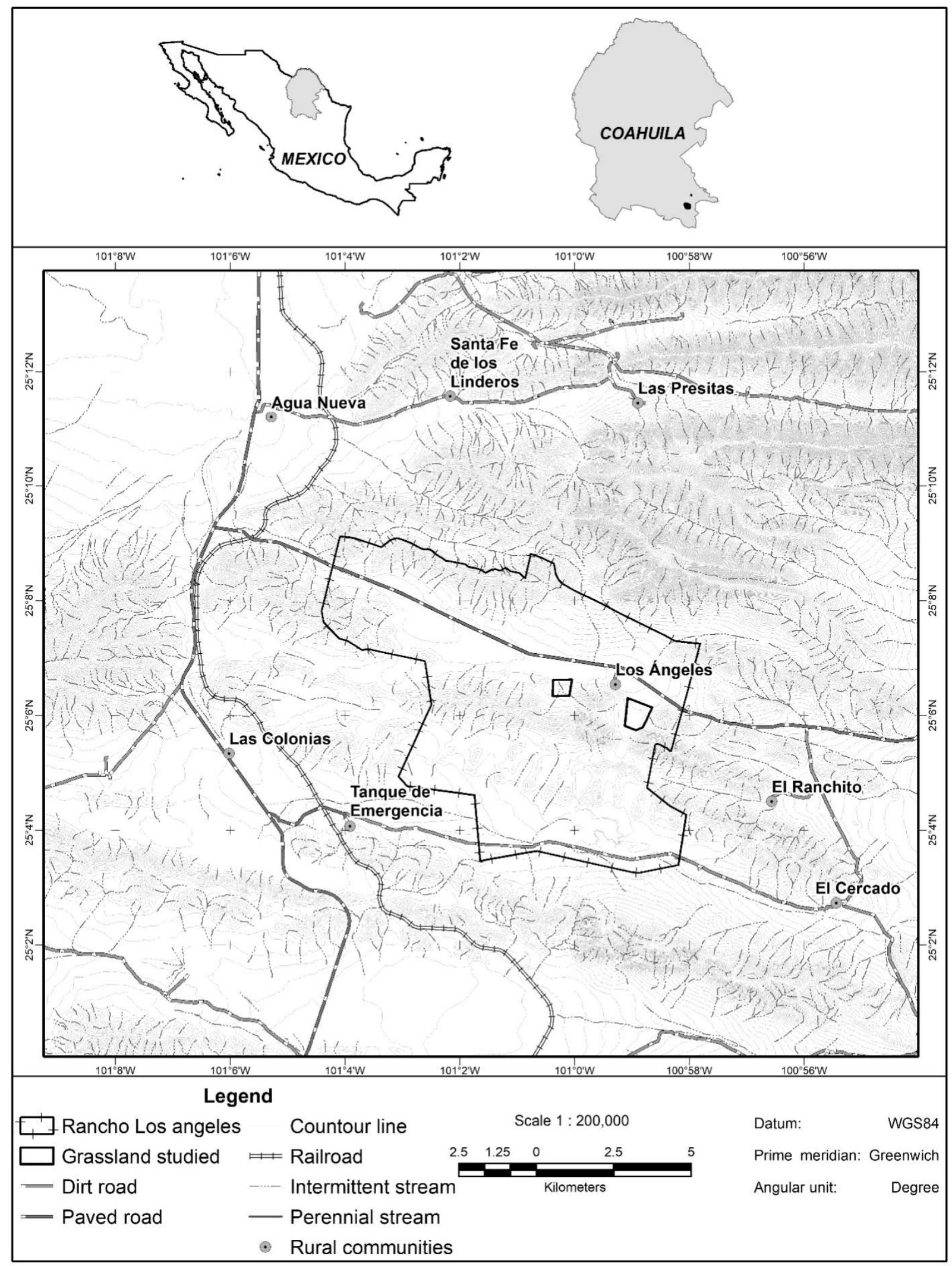

Figure 1. Location of the study area Rancho Los Angeles (enclosed by the thin black line polygon) in northern Mexico $\left(25^{\circ} \mathrm{N}\right)$. The two blocks of this study inside Rancho Los Angeles are enclosed in the two polygons in thick black lines.

Experimental plots were established in two agricultural areas abandoned in 2009—one with a surface area of 40 and the other 60 ha. After the suppression of the agricultural 
activity (mainly cereal with some short periods of opening for cattle grazing), spiny grass (Amelichloa clandestina) colonized the area, and gradually, a dense grassland was formed, where the herbaceous stratum has become dominant. The long use of these rangelands had an impact on the potential vegetation of the area, and restoration should be based on the native species composition of this particular area and reduction of shrubs, with the promotion of annual species highly affected by these longs' periods of use.

\subsection{The Species}

Amelichloa clandestina (Hack.) Arriaga \& Backworth (Poaceae) is a native perennial grass (Figure 2). The leaves are basal, erect, $10-50 \mathrm{~cm}$ long with a sharp brown tip when dry. It has tufted culms 40 to $100 \mathrm{~cm}$ high, erect, thin, internodes glabrous, 1-2 noded, with a rhizomatous base; sheaths are glabrous except on the neck, where they are hispid. The lower sheaths frequently hide cleistogamous inflorescences [20]; ligule, a small scale 0.1 to $0.2 \mathrm{~mm}$ long. Blades are 10 to $30 \mathrm{~cm}$ long, bent or generally involute, glabrous to scabrous with muchronous apex. The inflorescence is a narrow panicle 8 to $35 \mathrm{~cm}$ long. Spikelets have only one fertile floret. The floret has a densely bearded callus, and a twice geniculate awn, glabrous, and 12 to $20 \mathrm{~mm}$ long [21].

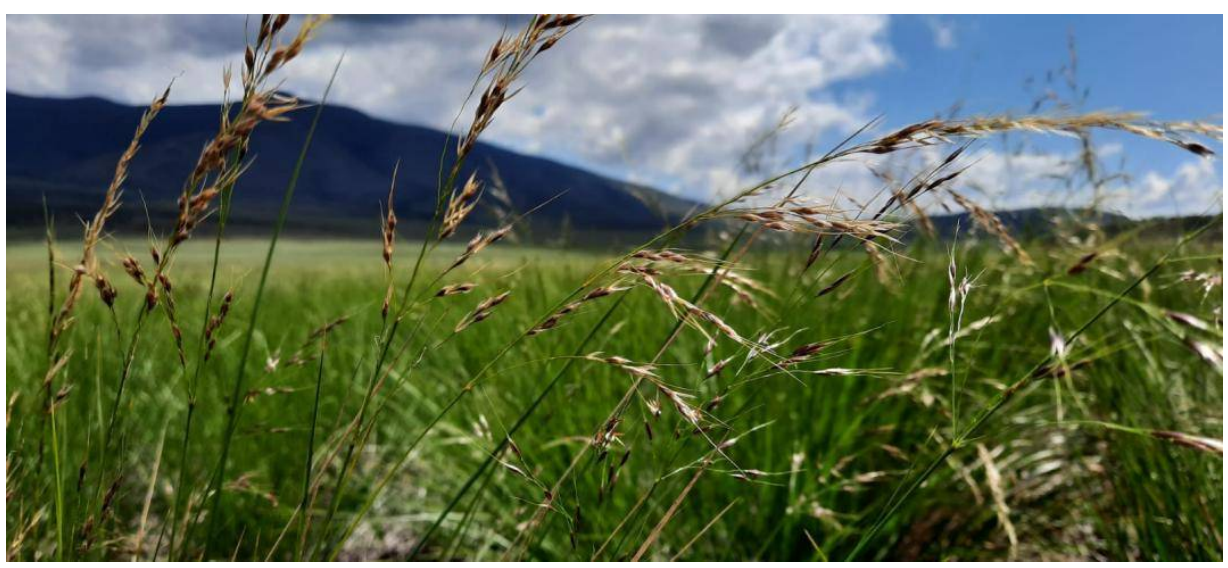

Figure 2. Inflorescence Amelichloa clandestina in the study site.

The species is distributed in Coahuila and Nuevo León, Mexico, and has been introduced to western Texas. Its presence was first recorded in the early 1950s [22]. Misidentification prevented it from being recorded until 1987. Since then, it has spread throughout the Edwards Plain and parts of central Texas [15]. It occurs in disturbed places, on calcareous soils, in impacted areas, grasslands, and pinyon pine forests between 800 and $2100 \mathrm{~m}$ altitude.

\subsection{Sampling}

Two blocks in two different pastures ( $1 \mathrm{~km}$ apart approximately) of 12 plots of $10 \times$ $10 \mathrm{~m}$ were established, with $5 \mathrm{~m}$ separation between plots, and four different treatments randomly assigned to the plots ( 2 blocks $\times 4$ treatments $\times 3$ replicates; Figure 3 ). In all these plots, the dominant grass is Amelichloa clandestine with over $95 \%$ cover of the plot. Treatments were applied in March 2020 before the rainy season and included the following: Treatment 1 (burn): Around the plots, $2 \mathrm{~m}$ wide fire breaks were made to isolate the vegetation where controlled burning was applied. The concentric burning technique was applied, which consists of making an ignition line at the end opposite to the wind direction, then ignition is started at the other end so that both lines meet and extinguish each other; Treatment 2 (herbicide): A minimum dose of glyphosate herbicide $\left(2.3 \mathrm{~L} \mathrm{ha}^{-1}\right.$ ) was homogenously applied on the plot, supplemented with $15 \mathrm{~mL}$ of liquid soap as an adherent; Treatment 3 (clipping): A. clandestina individuals were cut at a height of $5 \mathrm{~cm}$ from the ground, in spring. All cut foliage (leaves and culms) were removed from the 
plots; Treatment 4 (control): The case was considered as a control, in which the surface and species of the plots were not treated.
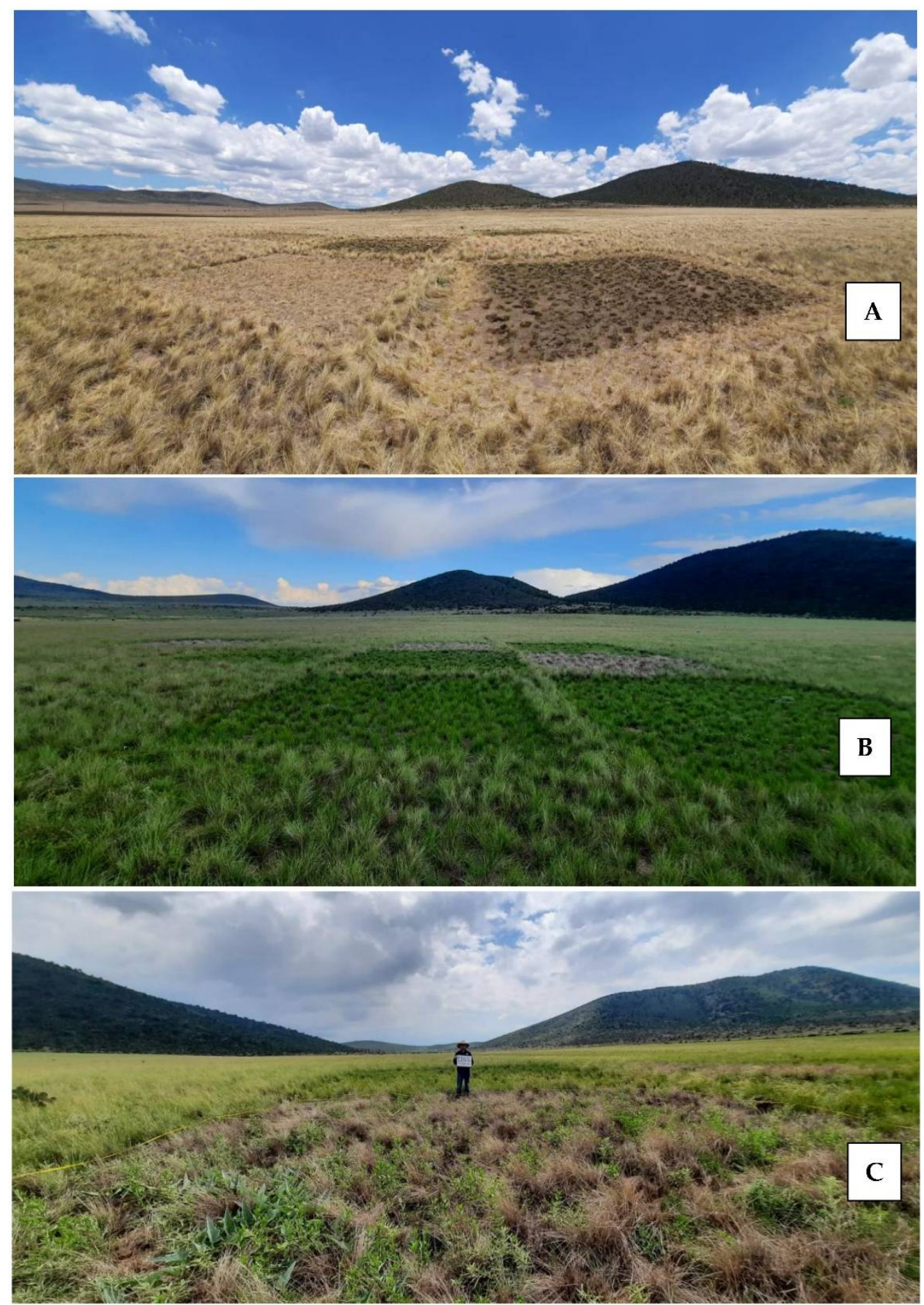

Figure 3. Grassland of Mexican needlegrass (Amelichloa clandestina): (A) application of burning and clipping treatments in foreground of the photo; $(\mathbf{B})$ response of the grass after application of treatments and during the rainy season in the following summer; (C) plot where the herbicide glyphosate was applied, in which a greater richness of species can be observed.

In each plot, we measured altitude, slope, and aspect. We also visually estimated rock, bare soil, and litter cover, as well as grass and forb cover (no woody species were present in the plots) within each plot on a scale of 1-10 (corresponding to percentage cover classes): 
1, traces; $2,0-1 \%$; 3, $1-2 \%$; 4, 2-5\%; 5, 5-10\%; 6, 10-25\%; 7, 25-50\%; 8, 50-75\%; 9, 75\%; 10 , $100 \%$ ). Additionally, the height of the grasses and forbs were measured (to identify the tallest ones in the plot).

In each plot, we recorded all plant species. Sampling was conducted from the end of August to the beginning of October 2020 (3 different sampling periods). This period encompassed the peak appearance of annual plants. Thus, most annual species present in the plots were recorded, including the alien species. Cover of species at ground level was estimated on a scale of 1-10 (previously defined).

\subsection{Statistical Analyses}

Ordination techniques help to explain community variation [23], and they can be used to evaluate trends over time and space [24]. We used detrended correspondence analysis (DCA) [25] of Software for Canonical Community Ordination (CANOCO) [24] to examine how species composition changed and whether the change could be attributed to the different treatments: control, clipping, herbicide, and burning.

To confirm differences in species composition based on treatment, we used the multiple-response permutation procedure (MRPP) in the PC-Ord statistical package [26]. MRPP, a non-parametric procedure, was used for testing the hypothesis that no difference existed in species composition between different plots. Relative Sørensen (Bray-Curtis) was used as a distance measure as it considers both composition (presence-absence of species) and abundance (cover values).

We conducted an analysis of similarity (ANOSIM) with 999 permutations to determine significant differences in species composition by treatment. This analysis provides pair tests among groups, thus helping to determine any differences. In order to identify species indicators for each group, the indicator species analyses (ISA) were implemented to determine the abundance and frequency of dominant species across the different treatments, and tests for statistical significance using a randomization technique (Monte Carlo) [27] were conducted. Both analyses (ANOSIM and ISA) were carried out with a PC-Ord statistical package [26].

Rock, soil, litter, grass, and forb cover (based on percentages), in addition to the evenness index of Smith and Wilson [28] and richness, were compared individually using a 2-way distance-based, permutational, repeated-measure ANOVA, with treatments used as factors (4 treatments and 6 plots in each one). Analysis was based on Bray-Curtis distances of raw data, with $p$-values obtained by using 9999 permutations of the appropriate exchangeable units [29]. Pairwise posteriori comparisons using $t$-statistics were applied when PERMANOVA revealed significant differences among groups (for a $p<0.05$ ). We used the same analysis to compare the cover of Amelichloa clandestina in the different treatments.

\section{Results}

The two blocks, which had been under similar management for the last 50 years, presented similar environmental conditions in terms of altitude, aspect, and slope (Table 1) and were separated by around $1 \mathrm{~km}$. In the case of grass and forb cover, the differences were statistically significant among treatments (Pseudo $F_{3,20}=27.17$ and Pseudo $F_{3,20}=9.35$, respectively, for a $p<0.01)$. The lowest values of grass cover were in herbicide plots $(20 \%)$, while the highest were in the control plots $(76 \%)$. However, forb cover was higher in the herbicide plots $(37 \%)$ and lower in the control and clipped plots $(5 \%)$, as indicated by the pairwise posteriori comparisons $(p<0.01)$. 
Table 1. General abiotic and plant community information of the plots ( ${ }^{*}$ Spc: Species richness; \#: number). Average values and standard deviation (Std) for the information of the different variables are also included.

\begin{tabular}{|c|c|c|c|c|c|c|c|c|c|c|c|c|}
\hline & Altitud & Aspect & Slope & Grasses & Forbs & Rock & Soil & Litter & Grasses & Forbs & $\mathrm{Spc} *$ & Evenness \\
\hline Plot** & $(\mathrm{m})$ & & (Sex) & & & $\%$ Cove & & & Heigh & $(\mathrm{cm})$ & $\#$ & \\
\hline CL21 & 2137 & 65 & 15 & 55 & 3 & 0 & 5 & 85 & 30 & 25 & 26 & 0.87 \\
\hline CL22 & 2117 & 85 & 25 & 40 & 5 & 15 & 10 & 50 & 40 & 50 & 22 & 0.78 \\
\hline CL41 & 2133 & 65 & 15 & 40 & 3 & 0 & 5 & 60 & 40 & 35 & 23 & 0.85 \\
\hline CL42 & 2125 & 85 & 25 & 45 & 2 & 10 & 20 & 45 & 50 & 20 & 24 & 0.86 \\
\hline CL61 & 2133 & 65 & 15 & 50 & 15 & 0 & 10 & 40 & 50 & 30 & 20 & 0.84 \\
\hline CL62 & 2119 & 85 & 25 & 45 & 2 & 12 & 10 & 40 & 40 & 8 & 30 & 0.83 \\
\hline Average & 2127.3 & & 20.0 & 45.8 & 5.0 & 6.2 & 10.0 & 53.3 & 41.7 & 28.0 & 24.2 & 0.8 \\
\hline Std & 8.2 & & 5.5 & 5.8 & 5.0 & 6.9 & 5.5 & 17.2 & 7.5 & 14.2 & 3.5 & 0.0 \\
\hline H101 & 2135 & 65 & 15 & 25 & 45 & 0 & 10 & 80 & 20 & 50 & 17 & 0.88 \\
\hline H102 & 2122 & 85 & 25 & 15 & 25 & 10 & 20 & 45 & 70 & 15 & 33 & 0.84 \\
\hline H121 & 2141 & 65 & 15 & 10 & 45 & 0 & 20 & 70 & 30 & 40 & 24 & 0.85 \\
\hline H122 & 2124 & 85 & 25 & 25 & 40 & 10 & 25 & 75 & 70 & 25 & 26 & 0.81 \\
\hline H81 & 2133 & 65 & 15 & 25 & 25 & 0 & 30 & 65 & 30 & 25 & 27 & 0.87 \\
\hline H82 & 2118 & 85 & 25 & 20 & 40 & 15 & 20 & 35 & 65 & 30 & 31 & 0.83 \\
\hline Average & 2128.8 & & 20.0 & 20.0 & 36.7 & 5.8 & 20.8 & 61.7 & 47.5 & 30.8 & 26.3 & 0.8 \\
\hline Std & 8.8 & & 5.5 & 6.3 & 9.3 & 6.6 & 6.6 & 17.8 & 23.2 & 12.4 & 5.6 & 0.0 \\
\hline B11 & 2139 & 65 & 15 & 60 & 5 & 0 & 10 & 5 & 28 & 30 & 32 & 0.83 \\
\hline B12 & 2116 & 85 & 25 & 40 & 5 & 10 & 30 & 5 & 30 & 25 & 27 & 0.82 \\
\hline B71 & 2133 & 65 & 15 & 30 & 15 & 0 & 20 & 5 & 30 & 35 & 29 & 0.87 \\
\hline B72 & 2125 & 85 & 25 & 40 & 5 & 30 & 35 & 3 & 35 & 20 & 31 & 0.81 \\
\hline B91 & 2133 & 65 & 15 & 30 & 15 & 0 & 30 & 5 & 35 & 30 & 32 & 0.81 \\
\hline B92 & 2122 & 85 & 25 & 35 & 30 & 5 & 45 & 5 & 35 & 20 & 35 & 0.85 \\
\hline Average & 2128.0 & & 20.0 & 39.2 & 12.5 & 7.5 & 28.3 & 4.7 & 32.2 & 26.7 & 31.0 & 0.8 \\
\hline Std & 8.5 & & 5.5 & 11.1 & 9.9 & 11.7 & 12.1 & 0.8 & 3.2 & 6.1 & 2.8 & 0.0 \\
\hline C111 & 2139 & 65 & 15 & 80 & 15 & 0 & 5 & 20 & 55 & 50 & 24 & 0.84 \\
\hline C112 & 2123 & 85 & 25 & 65 & 5 & 25 & 20 & 10 & 60 & 25 & 25 & 0.82 \\
\hline C31 & 2135 & 65 & 15 & 85 & 2 & 0 & 5 & 15 & 60 & 40 & 24 & 0.83 \\
\hline C32 & 2119 & 85 & 25 & 70 & 3 & 25 & 30 & 15 & 60 & 25 & 20 & 0.83 \\
\hline C51 & 2133 & 65 & 15 & 85 & 3 & 0 & 20 & 10 & 70 & 45 & 11 & 0.75 \\
\hline C52 & 2125 & 85 & 25 & 70 & 2 & 5 & 20 & 20 & 75 & 25 & 21 & 0.83 \\
\hline Average & 2129.0 & & 20.0 & 75.8 & 5.0 & 9.2 & 16.7 & 15.0 & 63.3 & 35.0 & 20.8 & 0.8 \\
\hline Std & 7.8 & & 5.5 & 8.6 & 5.0 & 12.4 & 9.8 & 4.5 & 7.5 & 11.4 & 5.2 & 0.0 \\
\hline
\end{tabular}

$\left({ }^{* *}\right)$ The letters indicated the treatment as CL: clipping; H: herbicide; B: burning; C: control.

A total of 70 species were found in the study (Appendix A), with a low number of introduced species (10). Richness varied significantly among treatments (Pseudo $\mathrm{F}_{3,20}=4.01$, $p<0.01)$, revealing higher values of species richness for burned plots $(p<0.01$; Figure $4 \mathrm{a})$. For evenness, differences were not significant $\left(\mathrm{F}_{3,20}=1.13, p=\right.$ n.s.; Figure $\left.4 \mathrm{~b}\right)$.

The DCA analysis discriminated among the different treatments along axis II. We represented the bidimensional space with the species and the plot coordinates, and polygons containing the plots of each treatment (minimum area polygons containing the plots). This species composition analysis revealed that control and clipping are poorly discriminated, and we also found low discrimination for control and herbicide plots. Amelichloa clandestina is more representative in terms of the species composition in the first two treatments than for burned or herbicide treatments. More exotic species are representative of the burned and herbicide treatments, such as Erodium cicutarium, Parthenium hysterophorus, Eruca sativa, Taraxacum officinale, or Sonchus oleraceus. For control and clipping, the most representative species, based on species composition, are Solidago velutina, Hesperostipa comata, Muhlenbergia rigida, Townsendia mexicana, Cylindropuntia imbricata, or Nassella tenuissima (Figure 5). 
(a)

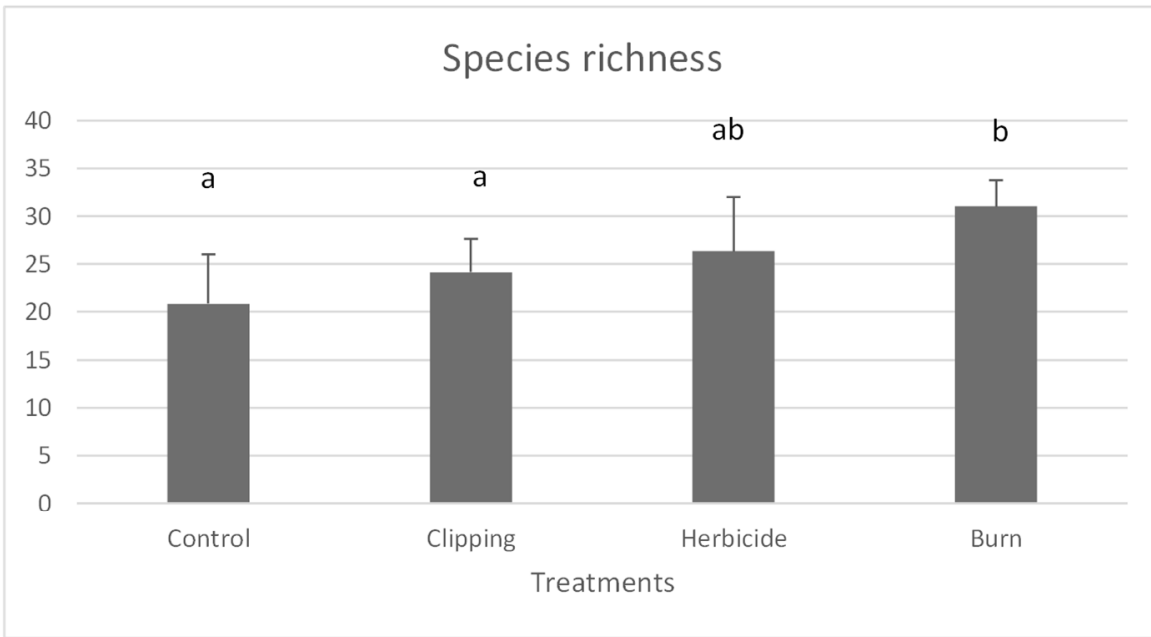

(b)

\section{Evenness}

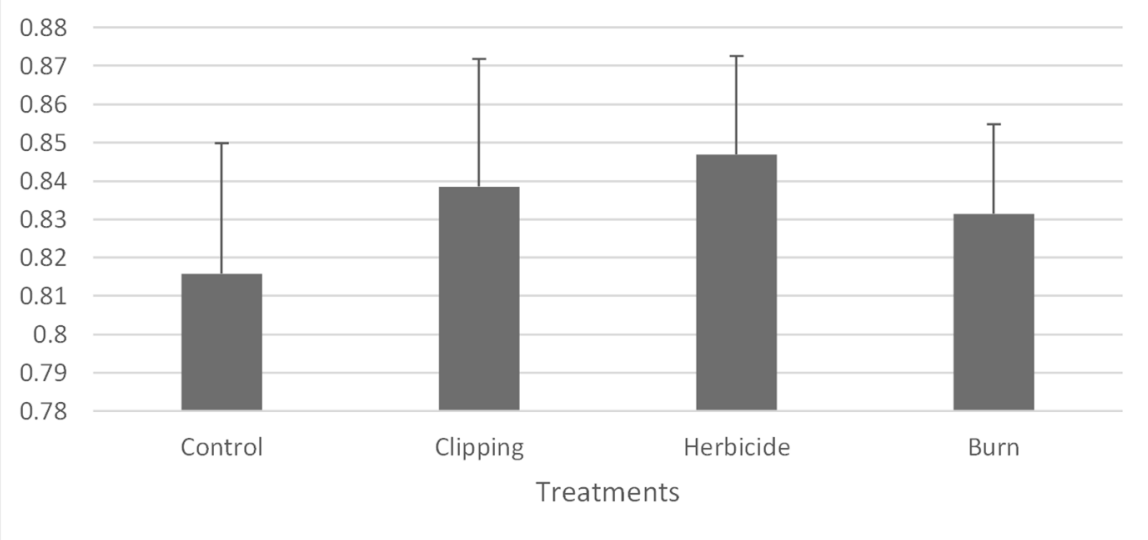

(c)

Cover Amelichloa clandestina

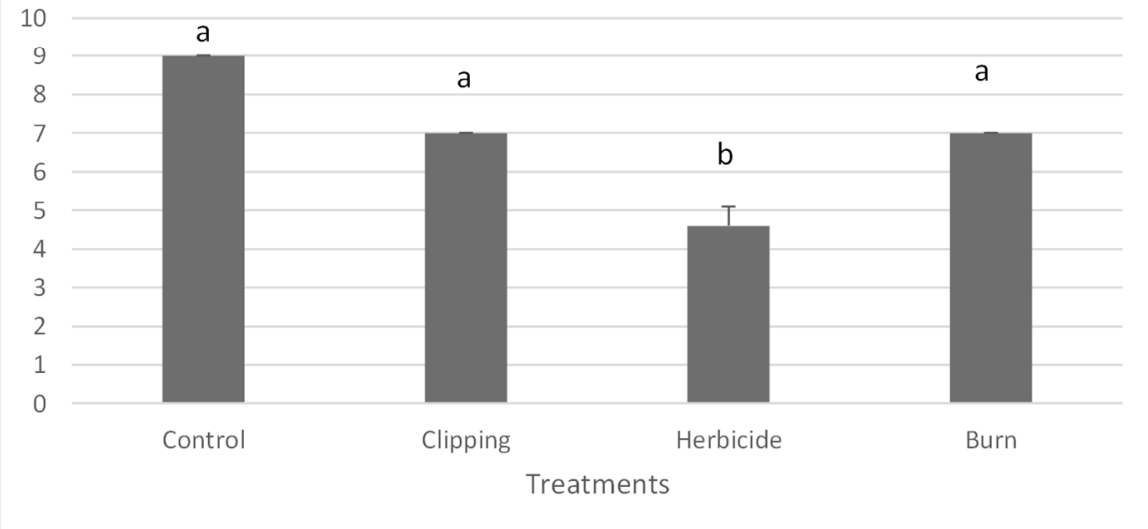

Figure 4. Mean values and standard deviations for (a) species richness, (b) evenness, and (c) cover of Amelichloa clandestina for the different treatments. Identical letters on top of bars indicate nonsignificant differences ( $p<0.05$ for d.f. $=23$ for the error term). 


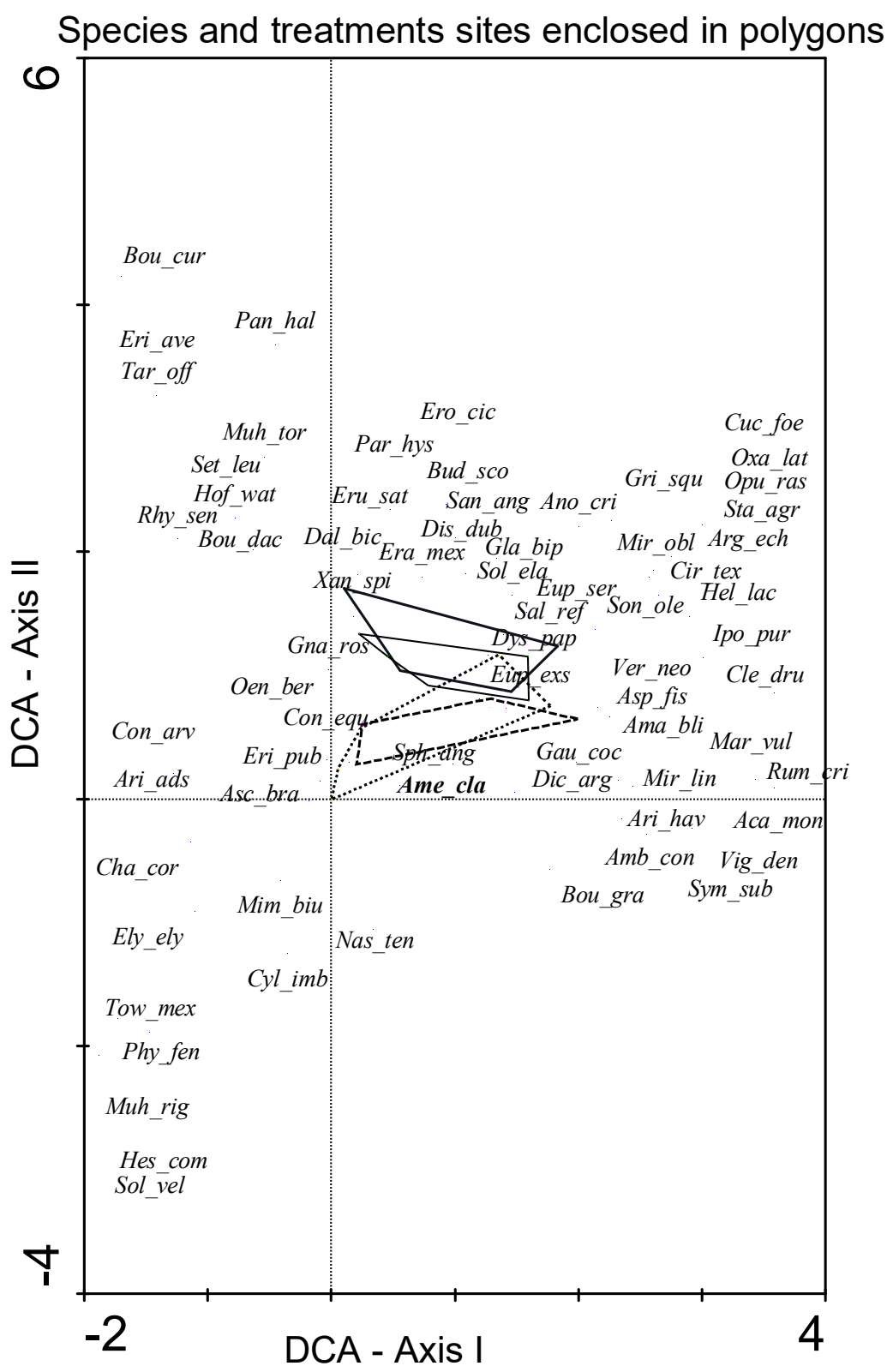

Figure 5. Detrended correspondence analysis axes I and II. Species coordinates and treatment plots' coordinates (each treatment with a different symbol). Eigenvalues for axis I: 0.30, eigenvalue for axis II: 0.14 , cumulative percentage of total inertia for axes I and II: $26.4 \%$. Polygons enclosed plots under same treatment: Polygon with a slashed line for control plots, dotted line for clipped plots, solid thick line for burned plots, and solid thin line for herbicide plots (species names use the three first letters of the genus, followed by the three first letters of the specific epithet from Appendix A).

Differences between treatments based on species cover were significant (MRPP), with a $\mathrm{T}=-3.551$ and group probability correction of $\mathrm{A}=0.058$ for $\mathrm{a} p<0.01$. ANOSIM was used to reveal the differences in paired treatments. We found evidence of significant variations among species groups for the different treatments $(R=0.2026, p<0.001$ for 1000 iterations). Indeed, pair comparisons revealed that control plot species compositions were significantly different from the burned and herbicide plots (both with a $p<0.01$ ).

Finally, the ISA base in 1000 permutations revealed that the species Anoda cristata, Erodium cicutarium, Euphorbia serrula, Parthenium hysterophorus, Sanvitalia angustifolia were indicators of burned plots, while Eruca sativa and Townsedia mexicana were indicators of herbicide and control plots, respectively. In all these cases, the indicator value (IV) was significant, with a $p<0.05$. 


\section{Discussion}

The study was carried out in an area after 12 years of agriculture abandonment. This area was colonized by Amelichloa clandestina, a plant that completely dominated the site and significantly reduced species richness. Farmland abandonment constitutes a major land use change, with its importance acknowledged today due to the implications it has for biodiversity and cultural values $[1,30]$. We suggested the use of three different management techniques in the area in order to increase native plant community and species composition. Mechanical treatments, such as clipping, reduce biomass and give species present in the seed bank the chance to occupy the open area, but these seeds will need to grow faster than the target species Amelichloa clandestina. In the case of herbicide treatment, glyphosate is a very potent one [31], whose usefulness in weed control has been recognized for over 25 years [32]. However, having no specific effect on the target species (it affects all the species treated), it is necessary to analyze its impact on the plant community before generalizing its use. Finally, burning is a useful management tool for preventing large wildfires [33], though it can have significant effects on diversity [34] and species composition [35], depending on how and where it is applied.

With regard to the plots, all of them presented similar environmental conditions (altitude, aspect, slope, and rock cover). However, plot characteristics related to the treatments revealed significant differences, as in the case of grass cover, with lower values in the herbicide plots and the highest values in the control plots. By contrast, forbs presented the largest cover in the herbicide-treated plots and lower cover in the control and clipped plots. Herbicide affected the dominant grass, favoring the cover of forbs (Table 1).

In the case of species richness, the burned plots presented the highest values (greater than 10 species more, on average, than control plots). This is an expected value, as most sources suggest an overall trend of increasing species richness after fire [36-38]. In most cases, this increase in richness occurs during the first-to-second year after fire and is related to herbaceous pioneer species [39], which are linked to canopy opening and higher light availability at the soil surface after fire [40]. In addition, herbicide plots presented a significantly high value of species richness due to the impact of the herbicide on the dominant grass, Amelichloa clandestina, as the open space allowed the occupancy of forbs, which have a faster response to this management (Figure 3A).

Non-significant differences were found for evenness among treatments, and although on average, control plots presented lower values (related to the dominance of Amelichloa clandestina), high variability did not allow for significant differences (Figure 3B). In the case of cover, A. clandestina showed some differences between treatments, with significantly lower values in the herbicide plots $\left(\mathrm{F}_{3,20}=129.63, p<0.01\right.$.; Figure $\left.3 \mathrm{C}\right)$.

In the case of species composition, the treatment that most differed from the control plots was burning, revealed by axis II of the DCA analysis. Some were more abundant in the control plots with respect to the treated plots, such as Solanum elaeagnifolium, Solidago velutina, Hesperostipa comata, Muhlenbergia rigida, or Townsendia mexicana, indicating they were favored after the abandonment of these fields, while in the case of the burned plots, Bouteloua curtipendula, Panicum hallii, Erioneuron avenaceum, or Muhlenbergia torreyi dominated, all of them grasses, alongside the forb Taraxacum officinale or Erodium cicutarium, both exotic forb species. Amelichloa clandestina was more abundant in the control and clipped plots, but its presence was reduced by the other treatments. The lowest cover of A. clandestina was present in the herbicide-treated plots.

The RPPP significantly differed between the groups, and the ANOSIM pair tests analyses revealed that species composition was different between control plots and burned and herbicide plots. The clipping did not produce any important difference with respect to the control plots, very likely due to the regrowth of perennial forbs, although mechanical removal has been effective in other experiments in different areas [41].

Indicator species of the burned plots that were identified in the analyses were all annuals (in some cases introduced ones, such as Erodium cicutarium or Parthenium hysterophorus). Other authors have found that competition from perennial grasses limits shrub 
production [42,43]. Eruca sativa, an introduced annual, characterized the herbicide plots and the native perennial forb, Townsendia mexicana, dominated the control plots.

Based on the results, two treatments appear to be more suitable approaches: burning, as a treatment to favor the increase in species richness, and herbicide to keep the dominance of Amelichloa clandestina under control. Regardless, we can discard the clipping methods, as the impact is very limited. Burning and herbicide treatments have the highest impact on species richness and composition in these highly disturbed rangelands.

\section{Conclusions}

Although the treatments revealed significant effects on species richness and composition, the presence of the target species was still substantial while being quite reduced relative to control plots. Burning appears to be effective, favoring an increase in species richness and revealing a less significant presence of Amelichloa clandestina, but with a dominance of annuals, a short-term common result after burning or wildfire [44]. The most significant reduction of $A$. clandestina cover was shown in the herbicide treatment.

In order to keep species under control, the use of periodical burning seems to be necessary, but exotic species can also be favored by this treatment; therefore, we can consider this an effective management technique to increase diversity. The herbicide, although important in reducing the cover of Amelichloa clandestina at the first application, when dominance is over $90 \%$ of cover, needs to be used with caution in reapplications to avoid an effect on native species. Other more complex biological treatments, such as the introduction of natural enemies of the target species [45], are riskier from an ecological point of view and require long experimental periods, though they can be highly recommended whenever they are possible and affordable.

The eradication methods, although useful, will require monitoring of the changes of the plant community, as long as we have seen that they can promote some exotic species that may need specific attention. To control their spreading, after burning, we suggest applying herbicide on individual plants of these species.

It is worth mentioning that the use of burning allows for the removal of part of the dominant species, which increases the time for invasive species to occupy the new area and therefore favors the recovery of natural vegetation, increasing species richness. However, we still recommend herbicide application to support the treatment of repeated burning to keep A. clandestina and other exotic species under control.

Author Contributions: Conceptualization, J.R.A. and J.A.E.-D.; data curation, J.A.E.-D., S.J.-M., J.A.N.-C., and P.Á.-V.; supervision, M.M. and J.A.E.-D.; project administration, J.A.E.-D.; review and editing, J.R.A., J.A.E.-D., and M.M. All authors have read and agreed to the published version of the manuscript.

Funding: This research received no external funding.

Acknowledgments: We wish to thank Ricardo Vázquez Aldape, responsible for ranch management, for allowing this research. We thank the Secretary of Environment of the state of Coahuila for allowing the fire brigade to carry out controlled burning in the study plots. We also wish to thank Eber G. Chávez, Erika J. Cruz, and Evelio Ramírez for the invaluable support during the establishment of the experimental plots, and Martín Torres and Yedid Vázquez for their help during field data collection. We thank Jerome Scorer for improving the English manuscript, and many thanks to Onofre Pastrana for preparing the map for the study area.

Conflicts of Interest: The authors declare no conflict of interest. 


\section{Appendix A}

Table A1. Species characteristics with the life cycle, origin, and growth form indicated. Bold use for introduced species.

\begin{tabular}{|c|c|c|c|}
\hline Species Name & Life Cycle & Origin & Growth Form \\
\hline Acalypha monostachya & Perennial & Native & Forb \\
\hline Amaranthus blitoides & Annual & Native & Forb \\
\hline Ambrosia confertiflora & Perennial & Native & Forb \\
\hline Amelichloa clandestina & Perennial & Native & Grass \\
\hline Anoda cristata & Annual & Native & Forb \\
\hline Argemone echinata & Annual & Native & Forb \\
\hline Aristida adscensionis & Perennial & Native & Grass \\
\hline Aristida havardii & Perennial & Native & Grass \\
\hline Asclepias brachystephana & Perennial & Native & Forb \\
\hline Asphodelus fistulosus & Perennial & Introduced & Forb \\
\hline Bouteloua curtipendula & Perennial & Native & Grass \\
\hline Bouteloua dactyloides & Perennial & Native & Grass \\
\hline Bouteloua gracilis & Perennial & Native & Grass \\
\hline Buddleja scordioides & Perennial & Native & Shrub \\
\hline Chamaesaracha coronopus & Perennial & Native & Forb \\
\hline Cirsium texanum & Perennial & Native & Forb \\
\hline Clematis drummondii & Perennial & Native & Shrub \\
\hline Convolvulus arvensis & Perennial & Introduced & Forb \\
\hline Convolvulus equitans & Perennial & Native & Forb \\
\hline Cucurbita foetidissima & Perennial & Native & Forb \\
\hline Cylindropuntia imbricata & Perennial & Native & Shrub \\
\hline Dalea bicolor & Perennial & Native & Shrub \\
\hline Dichondra argentea & Perennial & Native & Forb \\
\hline Disakisperma dubium & Perennial & Native & Grass \\
\hline Dyssodia papposa & Annual & Native & Forb \\
\hline Elymus elymoides & Perennial & Native & Grass \\
\hline Eragrostis mexicana & Annual & Native & Grass \\
\hline Erigeron pubescens & Perennial & Native & Forb \\
\hline Erioneuron avenaceum & Perennial & Native & Grass \\
\hline Erodium cicutarium & Annual & Introduced & Forb \\
\hline Eruca sativa & Annual & Introduced & Forb \\
\hline Euphorbia exstipulata & Annual & Native & Forb \\
\hline Euphorbia serrula & Annual & Native & Forb \\
\hline Gaura coccinea & Perennial & Native & Forb \\
\hline Glandularia bipinnatifida & Annual & Native & Forb \\
\hline Gnaphalium roseum & Perennial & Native & Forb \\
\hline Grindelia squarrosa & Perennial & Native & Forb \\
\hline Helianthus laciniatuus & Perennial & Native & Forb \\
\hline Hesperostipa comata & Perennial & Native & Grass \\
\hline Hoffmannseggia watsonii & Perennial & Native & Forb \\
\hline Ipomoea purpurea & Annual & Introduced & Forb \\
\hline Marrubium vulgare & Perennial & Introduced & Forb \\
\hline Mimosa biuncifera & Perennial & Native & Shrub \\
\hline Mirabilis linearis & Perennial & Native & Forb \\
\hline Mirabilis oblongifolia & Perennial & Native & Forb \\
\hline Muhelenbergia rigida & Perennial & Native & Grass \\
\hline Muhlenbergia torreyi & Perennial & Native & Grass \\
\hline Nassella tenuissima & Perennial & Native & Grass \\
\hline
\end{tabular}


Table A1. Cont.

\begin{tabular}{cccc}
\hline Species Name & Life Cycle & Origin & Growth Form \\
\hline Oenothera berlandieri & Perennial & Native & Forb \\
Opuntia rastrera & Perennial & Native & Shrub \\
Oxalis latifolia & Perennial & Native & Forb \\
Panicum hallii & Perennial & Native & Grass \\
Parthenium hysterophorus & Annual & Introduced & Forb \\
Physaria fendleri & Perennial & Native & Forb \\
Rhynchosia senna & Perennial & Native & Forb \\
Rumex crispus & Perennial & Introduced & Forb \\
Salvia reflexa & Annual & Native & Forb \\
Sanvitalia angustifolia & Annual & Native & Forb \\
Setaria leucopila & Perennial & Native & Grass \\
Solanum elaeagnifolium & Perennial & Native & Forb \\
Solidago velutina & Perennial & Native & Forb \\
Sonchus oleraceus & Annual & Introduced & Forb \\
Sphaeralcea angustifolia & Perennial & Native & Forb \\
Stachys agraria & Annual & Native & Forb \\
Symphyotrichum subulatum & Annual & Native & Forb \\
Taraxacum officinale & Perennial & Introduced & Forb \\
Townsedia mexicana & Perennial & Native & Forb \\
Verbena neomexicana & Perennial & Native & Forb \\
Viguiera dentata & Perennial & Native & Forb \\
Xanthisma spinulosum & Perennial & Native & Forb \\
\hline
\end{tabular}

\section{References}

1. Geeson, N.A.; Brandt, C.J.; Thornes, J.B. Mediterranean Desertification: A Mosaic of Processes and Responses; Wiley: Chichester, $\mathrm{UK}, 2002$.

2. Rackham, O. Holocene history of Mediterranean island landscapes. In Mediterranean Island Landscapes: Natural and Cultural Approaches; Vogiatzakis, I., Pungetti, G., Mannion, A.M., Eds.; Springer: Dordrecht, The Netherlands, 2008 ; pp. 36-60.

3. Palmer, C.; Colledge, S.; Bevan, S.; Conolly, J. Vegetation recolonisation of abandoned agricultural terraces on Antikythera, Greece. Environ. Archaeol. 2010, 15, 64-80. [CrossRef]

4. $\quad$ Rounsevell, M.D.A.; Reginster, I.; Araujo, M.B.; Carter, T.R.; Dendoncker, N.; Ewert, F.; House, J.I.; Kankaanpää, S.; Leemans, R.; Metzger, M.J.; et al. A coherent set of future land use change scenarios for Europe. Agric. Ecosyst. Environt. 2006, $114,57-68$. [CrossRef]

5. Hernández, M. Paisajes Agrarios y Medio Ambiente en Alicante: Evolución e Impactos Ambientales de Los Paisajes Agrarios Alicantinos, 1950-1995; Universidad de Alicante: Alicante, Spain, 1997.

6. Ruecker, G.; Schad, P.; Alcubilla, M.M.; Ferrer, C. Natural regeneration of degraded soils and site changes on abandoned agricultural terraces in Mediterranean Spain. Land Degrad. Dev. 1998, 9, 179-188. [CrossRef]

7. Lasanta, T.; García-Ruiz, J.M.; Pérez Rontomé, M.C.; Sancho, C. Runoff and sediment yield in a semi-arid environment: The effect of land management after farmland abandonment. Catena 2000, 38, 265-278. [CrossRef]

8. Aide, T.M.; Grau, H.R. Globalization, migration, and Latin American ecosystems. Science 2004, 305, 1915-1916. [CrossRef]

9. Cramer, V.A.; Hobbs, R.J.; Standish, R.J. What's new about old fields? Land abandonment and ecosystem assembly. Trends Ecol. Evol. 2008, 23, 104-112. [CrossRef]

10. Meiners, S.J.; Pickett, S.T.A.; Cadenasso, M.L. Exotic plant invasions over 40 years of old field succession: Community patterns and associations. Ecography 2002, 25, 215-223. [CrossRef]

11. Corbin, J.D.; D'Antonio, C.M. Competition between native perennial and exotic annual grasses: Implications for an historical invasion. Ecology 2004, 85, 1273-1283. [CrossRef]

12. Kulmatiski, A. Exotic plants establish persistent communities. Plant Ecol. 2006, 187, 261-275. [CrossRef]

13. Arévalo, J.R.; Fernández-Lugo, S.; Mellado, M.; de la Concepción, T. Experimental management control of Opuntia dillenii Haw. and Agave americana L. in the Teno Rural Park, Canary Islands. Plant Spec. Biol. 2015, 30, 137-146. [CrossRef]

14. Mellado, M.; Encina-Domínguez, J.A.; García, J.E.; Estrada-Castillón, E.A.; Arévalo, J.R. Vegetation response to removal of plant functional groups and grass seeding in a microphyllous desert shrubland: A 4-year field experimente. Agriculture 2021, 11, 322. [CrossRef]

15. Barkworth, M.E.; Valdes-Reyna, J.; Landers, R.Q., Jr. Stipa clandestina: New weed threat on southwestern rangelands. Weed Tech. 1989, 3, 699-702. [CrossRef]

16. Arévalo, J.R.; Tejedor, M.; Jiménez, C.; Reyes-Betancort, J.; Díaz, F.J. Plant species composition and richness in abandoned agricultural terraces vs. natural soils on Lanzarote (Canary Islands). J. Arid Environ. 2016, 124, 165-171. [CrossRef] 
17. Lesschen, J.P.; Cammeraat, L.H.; Nieman, T. Erosion and terrace failure due to agricultural land abandonment in a semi-arid environment. Earth Surf. Process. Landf. 2008, 33, 1574-1584. [CrossRef]

18. García, E. Modificaciones al Sistema de Clasificación Climática de Köeppen, 5th ed.; Instituto de Geografía-UNAM: Serie Libros, Mexico, 2004.

19. Domínguez-Aguilera, A.A. Evaluación de la Infiltración Final y la Producción de Sedimentos en Cinco Tipos de Vegetación, Bajo Tres Intensidades de Lluvia, en la Microcuenca "Los Ángeles" Saltillo, Coahuila. Licentiate Thesis, Universidad Autónoma Agraria Antonio Narro, Buenavista, Saltillo, Coahuila, Mexico, 2019.

20. Arriaga, M.O.; Barkworth, M.E. Amelichloa: A new genus in the Stipeae (Poaceae). SIDA 2006, 22, 145-149.

21. Valdes-Reyna, J. Gramíneas de Coahuila. Comisión Nacional para el Conocimiento y Uso de la Biodiversidad; Universidad Autónoma de Aguascalientes (UAA): Mexico City, Mexico, 2015.

22. Russell, M.L.; Landers, R.Q., Jr. Mexican Needlegrass; Texas A\&M AgriLife Extension Service; Tamu: College Station, TX, USA, 2017; pp. 1-4.

23. Gauch, H.G. Multivariate Analysis in Community Ecology; Cambridge University Press: Cambridge, UK, 1982.

24. Ter Braak, C.J.F.; Ŝmilauer, P. Canoco Reference Manual and User's Guide to Canoco for Windows: Software for Canonical Community Ordination (Version 4); Microcomputer Power: Ithaca, NY, USA, 1998.

25. Hill, M.O.; Gauch, H.J., Jr. Detrended Correspondence Analysis: An improved ordination technique. Vegetatio 1980, 42, 47-58. [CrossRef]

26. McCune, B.; Mefford, M.J. PC-Ord. Multivariate Analysis of Ecological Data, Version 2.0; MjM Software Design: Gleneden Beach, OR, USA, 1995.

27. McCune, B.; Grace, J.B.; Urban, D.L. Analysis of Ecological Communities; MjM Software Design: Gleneden Beach, OR, USA, 2002; Volume 28.

28. Smith, B.; Wilson, J.B. A consumer's guide to evenness indices. Oikos 1996, 76, 70-82. [CrossRef]

29. Anderson, M.; Gorley, R.; Clarke, K. Permanova + for Primer: Guide to Software and Statistical Methods; Primer-E Ltd.: Plymouth, UK, 2008.

30. Arévalo, J.R.; Fernández-Lugo, S.; Reyes-Betancort, J.A.; Tejedor, M.; Jiménez, C.; Díaz, F.J. Relationships between soil parameters and vegetation in abandoned terrace fields vs. non-terraced fields in arid lands (Lanzarote, Spain): An opportunity for restoration. Acta Oecol. 2017, 85, 77-84. [CrossRef]

31. Baird, D.D.; Upchurch, R.P.; Homesley, W.B.; Franz, J.E. Introduction of a new broad spectrum post emergence herbicide class with utility for herbaceous perennial weed control. In Proceedings of the North Central Weed Control Conference, Kansas City, MO, USA, 7-9 December 1971; pp. 64-68.

32. Diatloff, G. New uses of glyphosate. In Proceedings of the 12th Australian Weeds Conference Proceedings, Hobart, Tasmania, Australia, 12-16 September 1999; pp. 299-301.

33. Whelan, R.J. The Ecology of Fire; Cambridge University Press: Cambridge, UK, 1995.

34. Glasgow, L.S.; Matlack, G.R. Prescribed burning and understory composition in a temperate deciduous forest, Ohio, USA. For. Ecol. Manag. 2007, 238, 54-64. [CrossRef]

35. Baeza, M.J.; Vallejo, V.R. Vegetation recovery after fuel management in Mediterranean shrublands. Appl. Veg. Vci. 2008, 11, 151-158. [CrossRef]

36. Knapp, E.E.; Schwilk, D.W.; Kane, J.M.; Keeley, J.E. Role of burning season on initial understory vegetation response to prescribed fire in a mixed conifer forest. Can. J. Forest Res. 2007, 37, 11-22. [CrossRef]

37. Trabaud, L.; Lepart, J. Diversity and stability in garrigue ecosystems after fire. Vegetatio 1980, 43, 49-57. [CrossRef]

38. Lake, C.J.; Leishman, M.R. Invasion success of exotic plants in natural ecosystems: The role of disturbance, plant attributes and freedom from herbivores. Biol. Cons. 2004, 117, 215-226. [CrossRef]

39. Arévalo, J.R.; Fernández-Palacios, J.M. Natural regeneration of Pinus canariensis Chr. Sm. Ex DC in Buch in forest plantations after thinning. Open For. Sci. J. 2008, 1, 54-60. [CrossRef]

40. Boyd, C.S.; Svejcar, T.J. The influence of plant removal on succession in Wyoming big sagebrush. J. Arid Environ. 2011, 75, 734-741. [CrossRef]

41. Ganskopp, D.; Svejcar, T.; Taylor, F.; Farstvedt, J. Can spring cattle grazing among young bitter brush stimulate shrub growth? J. Rangel. Manag. 2004, 57, 161-168. [CrossRef]

42. Urness, P.J. Livestock as Manipulators of Mule Deer Winter Habitats in Northern Utah; USDA Forest Service: Fort Collings, CO, USA, 1990.

43. Holmgren, C.A.; Norris, J.; Betancourt, J.L. Inferences about winter temperatures and summer rains from the late Quaternary record of C4 perennial grasses and C3 desert shrubs in the northern Chihuahuan Desert. J. Quat. Sci. 2007, 22, 141-161. [CrossRef]

44. Arévalo, J.R.; Fernández-Lugo, S.; Naranjo, A.; Salas, M.; Ruíz, R.; Ramos, R.; Moreno, M. Post-fire recovery of an endemic Canarian pine forest. Int. J. Wildland Fire 2014, 23, 403-409. [CrossRef]

45. Hoffmann, J.H.; Moran, V.C.; Zeller, D.A. Long-term population studies and the development of an integrated management programme for control of Opuntia stricta in Kruger National Park, South Africa. J. Appl. Ecol. 1998, 35, 156-160. [CrossRef] 